\title{
GAMBARAN PATOLOGI HEPAR IKAN LELE DUMBO (Clarias gariepinus) YANG DIPAPAR LOGAM TIMBAL NITRAT Pb(NO$)_{2}$
}

\section{FEATURING LIVER PATHOLOGY OF AFRICAN CATFISH (Clarias gariepinus) THAT WERE EXPOSED BY LEAD NITRATE $\mathrm{Pb}\left(\mathrm{NO}_{3}\right)_{2}$}

\author{
Yolanda Dellavia 1), Thomas V. Widiyatno 2), Boedi Setiawan 2), \\ Arimbi 2), Bambang Poernomo 2), Yeni Damayanti 2) \\ 1) Mahasiswa, 2) Dosen \\ Fakultas Kedokteran Hewan Universitas Airlangga \\ Kampus C UNAIR, Jl. Mulyorejo-Surabaya 60115 \\ Telp. 031-5992785, Fax. 031-5993015 \\ Email: jbmvunair@gmail.com
}

\begin{abstract}
This research aimed to know the changed damage of liver African catfish (Clarias gariepinus) were exposed by lead nitrat. This study used twenty four of African catfish (Clarias gariepinus) with average weight of 20-25 grams, size 10-12 cm, age \pm two months. This research was designed by a completely randomized design (CRD). All member of population of the African catfish were divided into six groups, consist of six repetitions each, namely P1, P2, P3, and $\mathrm{P} 0$ as a negative control respectively. P1 was given with dosage of lead nitrat 7,26 mg/liter, P2 was given with dosage of lead nitrat $14,53 \mathrm{mg} /$ liter, and P3 was given with dosage of lead nitrat $29,06 \mathrm{mg} /$ liter. According to the macroscopic observed, show that liver became swollen and pale. The histopathological features of hepar were examined under light microscope in 400 times magnification. Scoring method were using Bernet Scoring Method to examined the presence of degeneretion, congesti, necrotic, and infiltration of leukocyte. Then, Kruskal-Wallis test through with Mann-Whitney test of statistical analysis. The statistical analysis showed the median number of P0 $(0,05)$, P1 $(0,45)$, P2 $(1,10)$, and P3 $(1,40)$ respectively. From the result can be concluded lead exposure with dose $29,06 \mathrm{mg} /$ liter severe which was heavily histopatological in hepatocytes cell of african catfish (Clarias gariepinus) liver.
\end{abstract}

Key words: Clarias gariepinus, Liver, Lead nitrat $\mathrm{Pb}\left(\mathrm{NO}_{3}\right)_{2}$

\section{PENDAHULUAN}

$\begin{array}{ccr}\begin{array}{c}\text { Kebutuhan } \\ \text { peningkatan }\end{array} & \text { seiring } & \text { mengalami } \\ \text { dengan }\end{array}$
pertambahan penduduk dan kesadaran masyarakat akan perbaikan gizi. Data statistik Kementerian Kelautan dan Perikanan menyatakan bahwa angka konsumsi ikan nasional pada tahun 2015 sebesar 41,11 kg/kap/tahun, dan mengalami peningkatan pada tahun 2016 sebesar 43,94 kg/kap/tahun. Salah satu ikan yang banyak dibudidayakan dan diminati oleh masyarakat adalah ikan lele dumbo (Clarias gariepinus) (Mahyuddin, 2008). Ikan lele dumbo diminati masyarakat karena memiliki beberapa kelebihan yakni pertumbuhan dan perkembangan optimal tercapai dalam waktu yang relatif singkat, tumbuh di lingkungan perairan tawar dan memiliki kemampuan yang tinggi dalam beradaptasi terhadap lingkungan (Purnamasari, 2012).

Peningkatan angka konsumsi ikan per tahun tidak diimbangi dengan peningkatan kualitas air yang menjadi ekosistem ikan lele dumbo (Clarias gariepinus). Evaluasi kualitas air sungai berdasarkan Keputusan Menteri Negara Lingkungan Hidup No. 115 Tahun 2003 tentang Pedoman Penentuan Status Mutu Air menyatakan bahwa terdapat 23 provinsi di Indonesia yang memiliki indeks kualitas air kurang dari target. 
Pencemaran perairan salah satunya disebabkan oleh pencemaran zat kimia logam timbal. Timbal merupakan jenis logam berat yang bersifat berbahaya dan bertindak sebagai kontaminan terhadap lingkungan di daerah industri perkotaan (Won-Yong et al., 2003).

Logam timbal ditemukan pada ekosistem perairan yang digunakan sebagai budidaya ikan lele di kota Pekalongan. Hasil analisis kandungan timbal pada sampel ikan lele menunjukkan adanya kandungan logam timbal yang berasal dari perairan budidaya ikan lele (Anindhita dkk., 2015). Toksisitas logam timbal dapat menimbulkan kerusakan pada jaringan sehingga mengakibatkan penurunan fungsi organ. Kerusakan jaringan yang terjadi akibat efek toksik timbal antara lain terjadi anemia, penurunan fungsi saraf, ginjal, hepar dan terjadi peningkatan tekanan darah (Wani et al., 2015).

Organ tubuh yang dapat
digunakan sebagai indikator pengamatan saat terjadinya akumulasi timbal pada perairan salah satunya adalah hepar. Hepar merupakan organ yang berperan penting dalam sistem metabolisme tubuh, sebagai alat sekresi dalam proses detoksifikasi dan memiliki sel kupfer yang berfungsi memfagosit benda asing yang masuk ke dalam tubuh (Pramyrtha dkk., 2014). Paparan timbal dalam lingkungan menyebabkan perubahan pada struktur jaringan hepar. Timbal terkonjugasi bersamaan dengan glutathione dan sebagian konjugatnya terakumulasi dalam jaringan hepar (Anderson, 2008). Timbal menginduksi penurunan produksi lipid, kolesterol dan glikogen dalam hepar secara biokimiawi. Logam timbal menghasilkan peningkatan aktivitas peroksidasi lipid-hepatic dan perubahan pada aktivitas enzim alkaline phosphatase dan enzim a-glycerophospate (Jarar and Taib, 2012).

Penelitian ini bertujuan untuk mengetahui perbedaan kerusakan organ hepar ikan lele dumbo (Clarias gariepinus) yang dipapar logam timbal nitrat $\mathrm{Pb}\left(\mathrm{NO}_{3}\right)_{2}$ dilihat dari tingkat dosis berbeda pada pemeriksaan patologis.

\section{MATERI DAN METODE PENELITIAN}

\section{Perolehan dan Penentuan Dosis Logam Timbal Nitrat $\mathrm{Pb}\left(\mathrm{NO}_{3}\right)_{2}$}

Logam timbal nitrat $\mathrm{Pb}\left(\mathrm{NO}_{3}\right)_{2}$ diperoleh dari Rofa Laboratorium Centre kota Bandung dalam bentuk serbuk putih. Prosedur penelitian melewati tiga tahap, yaitu uji pendahulan, uji toksisitas, dan uji perlakuan. Uji pendahuluan dilakukan dengan masa adaptasi ikan lele dumbo (Clarias gariepinus) selama dua hari, kemudian dilanjutkan dengan melakukan uji toksisitas.

\section{Persapan Hewan Coba}

Persiapan penelitian dilakukan selama satu hari sebelum ikan lele dumbo tiba. Sejumlah empat ember diisi air kemudian didiamkan selama 24 jam. Ember yang digunakan berwarna hitam, dengan maksud mengurangi tingkat stres ikan ketika berada di ember. Ikan lele dumbo (Clarias gariepinus) diadaptasikan di ember selama dua hari sebelum masa perlakuan. Ikan kan lele dumbo (Clarias gariepinus) diberi pakan berupa pelet selama masa adaptasi dan dijaga sirkulasi air agar cepat beradaptasi.

\section{Uji Toksisitas Logam Timbal Nitrat $\mathrm{Pb}\left(\mathrm{NO}_{3}\right)_{2}$}

Uji toksisitas dilakukan untuk mengetahui konsentrasi $\mathrm{LC}_{50}-96$ jam. Nilai LC $_{50}$ merupakan konsentrasi median lethal timbal nitrat yang menyebabkan mortalitas (kematian) $50 \%$ hewan uji. Uji toksisitas dilakukan 96 jam untuk mengetahui tingkat racun zuatu zat toksik (Yulianto, 2012). 


\section{Pelaksanaan Penelitian}

Ikan lele dumbo (Clarias gariepinus) sebanyak 18 ekor diletakkan pada tiga akuarium, masing - masing sebanyak enam ekor. Ikan lele dumbo (Clarias gariepinus) pada kelompok perlakuan P1 dimasukkan ke dalam akuarium dan dimasukkan logam timbal nitrat $\mathrm{Pb}\left(\mathrm{NO}_{3}\right)_{2}$ dengan dosis 7,26 $\mathrm{mg} /$ liter ke dalam air. Kelompok perlakuan $\mathrm{P} 2$ dengan dosis $\mathrm{Pb}\left(\mathrm{NO}_{3}\right)_{2}$ sebesar 14,53 mg/liter, P3 dengan dosis $\mathrm{Pb}\left(\mathrm{NO}_{3}\right)_{2}$ sebesar $29,06 \mathrm{mg} /$ liter.

Perlakuan dilakukan selama 30 hari, hal ini dikarenakan waktu paruh timbal pada jaringan sekitar 30 hari (Kurnijasanti dkk., 2017). Pada hari ke31 ikan diambil menggunakan penyaring ikan. Ikan yang sudah diambil dari akuarium dilakukan eutanasia menggunakan minyak cengkeh yang dilarutkan dalam air dengan dosis 0,21 ml/liter selama 15 menit (Morina dkk., 2017). Ikan lele dilakukan pembedahan setelah tahap eutanasia selesai. Organ hepar yang telah dikeluarkan dari tubuh ikan dilakukan pemeriksaan patologis secara makroskopis dan dilakukan pembuatan preparat histopatologi hepar.

\section{Pembuatan Preparat Histopatologi Hepar}

Eutanasia dilakukan setelah hari ke-31, kemudian dilakukan pengam- bilan organ hepar. Organ hepar yang telah dikeluarkan dari tubuh ikan dilakukan pemeriksaan patologis secara makroskopis dan dilakukan pembuatan preparat histopatologi hepar. Metode yang digunakan untuk membuat preparat histopatologi adalah metode rutin yang terdiri dari tahap fiksasi jaringan, dehidrasi, clearing, impregnasi, embedding, pengocokan jaringan, inkubasi, perwarnaan, dan pemasangan pada gelas obyek (Pramyrtha dkk., 2013).

\section{Pemeriksaan Makroskopis dan Mikroskopis}

Pemeriksaan perubahan patologi organ hepar ikan lele dumbo dilakukan dengan mengamati secara langsung perubahan dari organ hepar. Pengamatan secara fisik dilakukan dengan cara membandingkan organ hepar ikan lele dumbo perlakuan dengan organ hepar ikan lele dumbo kontrol. Pemeriksaan mikroskopis organ hepar ikan lele dumbo (C. gariepinus) dilakukan dengan cara pembuatan preparat histopatologi dan diamati di bawah mikroskop pembesaran 400 kali. Gambaran histopatologi hepar menurut Bernet et al (1999) dinilai berasarkan skoring derajat kerusakan hepar menggunakan skor mulai $0-6$ tergantung derajat dan luasnya perubahan seperti pada Tabel 1 di bawah ini :

Tabel 1. Penilaian gambaran histopatologi hepar ikan lele dumbo (Bernet et al., 1999)

\begin{tabular}{|c|c|l|}
\hline Bentuk Lesi & Skoring & \multicolumn{1}{|c|}{ Keterangan } \\
\hline & 0 & Tidak terjadi kongesti \\
& 2 & $\begin{array}{l}\text { Terjadi kongesti kurang dari sepertiga lapangan pandang } \\
\text { Kongesti }\end{array}$ \\
& 6 & $\begin{array}{l}\text { Terjadi kongesti lebih dari sepertiga sampai dengan } \\
\text { duapertiga lapangan pandang } \\
\text { Terjadi kongesti lebih dari duapertiga sampai dengan } \\
\text { seluruh lapangan pandang }\end{array}$ \\
\hline
\end{tabular}




\begin{tabular}{|c|l|l|}
\hline $\begin{array}{c}\text { Degenerasi } \\
\text { jaringan } \\
\text { hepar }\end{array}$ & 2 & $\begin{array}{l}\text { Tidak terjadi degenerasi } \\
\text { Terjadi degenerasi kurang dari sepertiga lapangan pandang } \\
\text { Terjadi degenerasi lebih dari sepertiga sampai dengan } \\
\text { duapertiga lapangan pandang } \\
\text { Terjadi degenerasi lebih dari duapertiga sampai dengan } \\
\text { seluruh lapangan dengan seluruh lapangan }\end{array}$ \\
\hline Inflamasi & 4 & $\begin{array}{l}\text { Terjadi inflamasi lebih dari sepertiga sampai dengan } \\
\text { duapertiga lapangan pandang } \\
\text { Terjadi inflamasi lebih dari duapertiga sampai dengan } \\
\text { seluruh lapangan pandang }\end{array}$ \\
\hline Tidak terjadi iflamasi \\
\hline Nekrosis sel \\
hepar
\end{tabular}

\section{Analisis Data}

Penelitian ini menggunakan analisis data dari uji statistik non parametrik yang disusun dalam bentuk tabel kemudian dianalisis menggunakan perangkat lunak komputer SPSS 21 for windows. Pengolahan data menggunakan uji Krusskal Wallis. Apabila terdapat perbedaan antar perlakuan dilanjutkan dengan uji Mann Whitney dengan taraf signifikan 0,05 (Jayanti, 2015).

\section{HASIL DAN PEMBAHASAN}

\section{Gejala Klinis Ikan Lele Dumbo}

Gejala klinis yang tampak pada ikan lele dumbo (Clarias gariepinus) yang dipapar logam timbal nitrat $\mathrm{Pb}\left(\mathrm{NO}_{3}\right)_{2}$ menunjukkan adanya whitespot, jejas erosi, ukuran tubuh membengkak, dan kulit berwarna kuning mengkilat. Penurunan kualitas air yang dicampur dengan logam timbal nitrat menyebabkan munculnya parasit dalam air. Epitel kulit ikan lele dumbo yang rentan oleh paparan logam timbal nitrat $\mathrm{Pb}\left(\mathrm{NO}_{3}\right)_{2}$ menyebabkan kulit ikan lele dumbo (Clarias gariepinus) mudah terserang parasit Ichthyophthirius multifiliis sehingga menyebabkan gejala Whitespot (Michael, 2015).

Jejas erosi terjadi sebagai sistem pertahanan kulit terhadap hygiene yang buruk menyebabkan ikan lele dumbo (Clarias gariepinus) mengalami stres (Tyas dkk., 2017). Stres mengakibatkan sel melakukan proses adaptasi, namun apabila sel tidak mampu beradaptasi maka akan menyebabkan terjadinya jejas/luka. 
Warna tubuh ikan lele dumbo (Clarias gariepinus) menjadi kekuningan. Hal tersebut disebabkan karena terjadinya bile imbibition, dimana empedu dalam gall bladder akan penetrasi pada dinding pembuluh darah dan mewarnai jaringan sekitar. Logam timbal masuk kedalam peredaran darah menyebabkan daerah abdomen ikan lele dumbo (Clarias gariepinus) membengkak oleh karena akumulasi cairan yang ada dalam rongga abdomen secara berlebihan atau biasa disebut edema.

\section{Patologi Makroskopis Hepar}

Kelompok perlakuan P1, P2 dan P3 organ hepar ikan lele dumbo (Clarias gariepinus) mengalami perubahan, yakni adanya lesi dan hemorraghi pada permukaan organ, organ tampak membesar dan warna organ nampak kuning mengkilat. Perbersaran organ hepar ikan lele dumbo (Clarias gariepinus) kelompok P1, P2, dan P3 disebabkan oleh perbesaran ukuran sel hepar. Perbesaran ukuran sel hepar terjadi karena terjadi akumulasi cairan di sitoplasma disebabkan meningkatnya kerja organ hepar untuk menetralkan serta menghilangkan zat toksin logam timbal yang masuk ke dalam peredaran darah.

\section{Patologi Mikroskopis Hepar}

Kerusakan yang terjadi akibat paparan logam timbal nitrat pada ikan lele dumbo (Clarias gariepinus) antara lain terjadinya degenerasi sel hepar, kongesti, nekrosis, dan inflamasi. Hasil skoring yang dianalisis menggunakan uji Kruskall Wallis menunjukkan adanya perbedaaan nyata $(\mathrm{P}<0,05)$ antar tiap kelompok P0, P1, P2 dan P3. Tahap selanjutnya uji Mann-Whitney menunjukkan adanya perbedaan nyata pada kelompok P0 dengan P1, P2, dan P3. P1 berbeda nyata dengan P2 dan P3, sedangkan P2 tidak berbeda nyata dengan kelompok P3. Kelompok P2 dan P3 tidak menunjukkan kerusakan yang berbeda nyata $(p>0,05)$. Hasil nilai median skoring hepar menunjukkan kerusakan paling rendah terjadi pada kelompok P1 dan kerusakan paling tinggi terjadi pada kelompok P3. Dosis logam timbal nitrat dinaikkan, maka kerja hepar ikan lele dumbo (Clarias gariepinus) semakin berat (Junqueira and Carneiro, 2005) seperti pada tabel 2 di bawah ini:

Tabel 2. Hasil skoring hepar ikan lele dumbo menggunakan uji Kruskall Wallis

\begin{tabular}{|c|l|c|}
\hline Perlakuan & \multicolumn{1}{|c|}{ Keterangan } & Median \\
\hline $\mathrm{P} 0$ & Tanpa dipapar logam timbal nitrat $\mathrm{Pb}\left(\mathrm{NO}_{3}\right)_{2}$ & $0,05^{\mathrm{a}}$ \\
\hline $\mathrm{P} 1$ & $\begin{array}{l}\text { Dipapar logam timbal nitrat } \mathrm{Pb}\left(\mathrm{NO}_{3}\right)_{2} \text { dengan dosis } \\
7,26 \mathrm{mg} / \mathrm{L}\end{array}$ & $0,45^{\mathrm{b}}$ \\
\hline $\mathrm{P} 2$ & $\begin{array}{l}\text { Dipapar logam timbal nitrat } \mathrm{Pb}\left(\mathrm{NO}_{3}\right)_{2} \text { dengan dosis } \\
14,53 \mathrm{mg} / \mathrm{L}\end{array}$ & $1,10^{c}$ \\
\hline $\mathrm{P} 3$ & $\begin{array}{l}\text { Dipapar logam timbal nitrat } \mathrm{Pb}\left(\mathrm{N}_{3}\right)_{2} \text { dengan dosis } \\
29,06 \mathrm{mg} / \mathrm{L}\end{array}$ & $1,40 \mathrm{c}$ \\
\hline
\end{tabular}

Keterangan: Superskrip yang berbeda pada kolom yang sama menunjukkan perbedaan yang nyata $(\mathrm{P}<0,05)$. 
Kelompok perlakuan ikan lele dumbo (Clarias gariepinus) menunjukkan adanya kongesti pada preparat histopatologi organ hepar ikan lele dumbo (Clarias gariepinus). Kongesti pada hepar ikan lele dumbo (Clarias gariepinus) dimulai dari vena porta, kemudian meluas sampai sinusoid yang di dalamnya terdapat eritrosit akibat pecahnya dinding sinusoid. Sel hepar mengalami degenerasi apabila terdapat vakuolisasi pada sitoplasma tetapi inti sel hepar masih normokromatik (Darmawan, 2003). Degenerasi terjadi akibat rusaknya membran plasma sel sehingga sodium dan air masuk ke dalam sel dan potassium keluar sel. Penurunan aktivitas pompa sodium dan air pada membran sel mengakibatkan peningkatan cairan di dalam sel. Degenerasi hidrofik adalah pembengkakan sel hepar, dimana terlihat adanya ruang-ruang kosong di dalam sitoplasma dari sel. Vakuola tampak membesar sehingga mendesak nukleus ke tepi sel. Degenerasi lemak ditandai dengan penampakan histopatologi berupa vakuola kosong.

Kelompok P1， P2, dan P3 menunjukkan hepatosit mengalami nekrosis. Radikal bebas menyebabkan terjadinya peningkatan jumlah kalsium dalam sitoplasma. Peningkatan jumlah kalsium dalam sitoplasma menyebabkan pelepasan beberapa enzim yang merusak membran sel seperti phospholipase, protease dan endonuclease sehingga terjadi kematian sel. Inti sel yang mengalami nekrosis tampak menyusut, batasnya tidak teratur dan berwarna gelap yang disebut piknotis. Terdapat bentukan inti sel hepar tampak hancur dan meninggalkan pecahan-pecahan zat kromatin yang tersebar dalam sel yang disebut karyorrhexis. Inti sel yang tampak hilang/lisis sehingga menyebabkan sel kehilangan kemampuan saat proses pewarnaan disebut kariolisis.

\section{KESIMPULAN}

Hasil statistik kerusakan organ hepar ikan lele dumbo menunjukkan nilai median kerusakan paling tinggi terjadi pada kelompok P3 dan paling rendah pada kelompok P0. Hal tersebut menunjukkkan semakin tinggi dosis logam timbal nitrat yang diberikan pada ikan lele dumbo (Clarias gariepinus), semakin tinggi pula tingkat kerusakan yang dihasilkan. Hasil skoring yang dianalisis menggunakan uji Kruskall Wallis menunjukkan adanya perbedaaan nyata $(\mathrm{P}<0,05)$ antar tiap kelompok $\mathrm{P} 0$, P1, P2 dan P3. Tahap selanjutnya uji Mann-Whitney menunjukkan adanya perbedaan nyata pada kelompok P0 dengan P1, P2, dan P3. P1 berbeda nyata dengan P2 dan P3, sedangkan P2 tidak berbeda nyata dengan kelompok $\mathrm{P} 3$.

\section{DAFTAR PUSTAKA}

Anderson. 2008. Buku Ajar Biokimia. (Diterjemahkan oleh R.F.Mulany). EGC. Jakarta.

Anindhita, M.A., Rusmalina, S., dan Soeprapto, H. 2015. Analisis Logam Berat Timbal $(\mathrm{Pb})$ pada Ikan Lele (Clarias sp.) yang Dibudidayakan di Kota Pekalongan. J. Ilmu Pengetahuan dan Teknologi. 28(2) : 210-215.

Bernet, D., Schmidt, H., Meier, W., Burkhardt, P., and Wahli, T. 1999. Histopathology in Fish : Proposal for Protocol to Assess Aquatic Pollution. J. Fish Dis. 22(1):25-34.

Darmawan S. 2003. Hati dan Saluran Empedu. UI Press. Jakarta.

Jarar, B.M., and Taib, N.T. 2012. Histological and Histochemical Alterations in The Liver Induced by Lead Chronic Toxicity. Saudi J. Of Biological Sciences. 19: 203 210. 
Junqueira, L.C., and Carneiro, J. 2005. Basic Histology 11th Edition. Mc Graw-Hill Medical. New York.

Kementrian Kelautan dan Perikanan. 2017. Data Statistik Kementrian Kelautan dan Perikanan. [Diakses pada tanggal 21 November 2017].

Kurnijasanti, R., Meles, D.K., Sudjarwo, S.A., Juniastuti, T., dan Hamid, I.S. 2017. Farmakoterapi dan Toksikologi. Duta Persada Press. Surabaya. Hal. 134-136.

Mahyuddin, K. 2008. Panduan Lengkap Agribisnis Lele. Penebar Swadaya. Jakarta. Hal. 6 - 15.

Michael, K.S. 2015. Laboratory Animal Medicine (Third Edition) Chapter 21 - Biology and Management of Laboratory Fishes. Elsevier Ltd. Amsterdam. 1063-1086.

Morina, G., Zainuddin, dan Masyitha 2017. Struktur Histologi Empedu dan Pankreas Ikan Lele Lokal (Clarias bathracus). JIMVET. 2(1): 30-34.

Pramyrtha, E., Anwar, C., Kuncorojakti, S., dan Yustinasari, L.R. 2014. Buku Ajar Histologi Veteriner Jilid 2 Departemen Anatomi Veteriner Fakultas Kedokteran Hewan Universitas Airlangga. PT. Revka Petra Media. Surabaya. Hal. 29-35.
Pramyrtha, E., Anwar, C., Kuncorojakti, S., dan Yustinasari, L.R. 2013. Buku Ajar Histologi Veteriner Jilid 1. Departemen Anatomi Veteriner. Fakultas Kedokteran Hewan Universitas Airlangga. Surabaya.

Purnamasari. 2012. Tingkat Infeksi Ektoparasit pada Benih Ikan Lele Dumbo (Clarias gariepinus) [Skripsi]. Fakultas Ilmu Kelautan dan Perikanan Universitas Hasanuddin Makasar.

Tyas, M., Rochman, B., dan Ratnaningrum, K. 2017. Buku Ajar Sistim Integumen FK Universitas Muhammadyah. Semarang. Unismus Press.

Wani, L.A., Anjum, A.R.A., and Usmani, J.A. 2015. Lead Toxicity. Interdiscip Toxicol. 8(2): 55-64.

Won-yong, S., Eun, J.S., Enrico, M., Yong, J.L., Yong-yell, Y., Michal, J., Cyrille, F., Inwhan, H., and Youngsook, L. 2003. Engineering Tolerance and Accumulation of Lead and Cadmium in Transgenic Plants. Nature Publishing Group. 21(8): 914-919.

Yulianto, B. 2012. Buku Ajar Ekotoksikologi: Uji Toksisitas Akut. Fakultas Perikanan dan Ilmu Kelautan Universitas Diponegoro. Semarang. Hal. 22. 